\title{
IDENTITY FORMATION IN THE NEW TESTAMENT
}

Author:

Markus Cromhout ${ }^{1}$

\section{Affiliation:}

${ }^{1}$ Department of New

Testament Studies, Faculty of Theology, University of Pretoria

\section{Correspondence to:}

Markus Cromhout

e-mail:

mcromhout@nac-sea. org.za

\section{Postal address:}

PO Box 1078, Sunninghill

2157, South Africa

\section{Keywords:}

identity formation;

intertextuality; literary

theory; gender studies;

postcolonial theory

Dates:

Received: 02 June 2009

Accepted: 13 July 2009

Published: 19 Nov. 2009

How to cite this article: Cromhout, M., 2009,

'Identity formation in the New Testament', HTS Teologiese Studies/ Theological Studies 65(1), Art. \#276, 12 pages. DOI: 10.4102/hts.v65i1.276

This article is available at:

http://www.hts.org.za

\section{Note:}

Dr Markus Cromhout is a research associate of Prof. Dr Andries G. van Aarde, Professor Emeritus, Department of New

Testament Studies, Faculty of Theology, University of Pretoria.

(C) 2009. The Authors. Licensee: OpenJournals Publishing. This work is licensed under the Creative Commons Attribution License.

\section{ABSTRACT}

This article is a review of the book entitled Identity Formation in the New Testament (edited by Bengt Holmberg and Mikael Winninge, Mohr Siebeck, Tübingen, 2008). It is a collection of various articles using intertextuality, literary theory (and social identity approaches), gender studies and postcolonial theory when investigating identity formation in the New Testament.

\section{INTRODUCTION}

This collection of articles is the result of the Nordic New Testament Conference held on 18-22 August 2007 at Sundsgårdens Folkhögskola (college of higher education) near Helsingborg in southern Sweden. Initial lectures and seminar discussions held at this event evolved into this volume entitled Identity Formation in the New Testament (2008), published by Mohr Siebeck and edited by Bengt Holmberg (Professor Emeritus, Lund University) and Mikael Winninge (Associate Professor, Umeå University). As the editors explain, the volume focuses on 'different means of identity formation and identity negotiation in New Testament times as well as in the history of reception of the New Testament' (Holmberg \& Winninge 2008:v). The bulk of the authors are Scandinavian scholars and PhD candidates, while the United Kingdom and Australia have one representative each. The volume also boasts an index of modern authors, a full bibliography, an index of ancient sources, as well as an index of subjects and terms.

The volume contains 14 articles and uses several ways to analyse identity formation in the New Testament, namely intertextuality, literary (and social identity) approaches, gender studies and postcolonial theory. The editors write that, hopefully, 'the application of so many different interpretive perspectives and approaches to the phenomenon of early Christian identity formation will help the reader to see how it emerges and appears in all its bewildering and intriguing complexity' (Holmberg \& Winninge 2008:ix). This may be somewhat misleading, as this volume does not exhaust all methods for investigating identity. One can therefore protest that the book is limited in its scope, but it needs to be judged on its own merit, bearing in mind that it is the result of a conference that had various contributors to specific focus areas, conveniently brought together here for general consumption under four methodological approaches. Certainly that is enough, even more than enough, for one volume. We will now proceed to review each method of analysing identity formation in the New Testament and the various contributions in the sequence in which they appear in the volume. Author details and full titles of the articles are provided.

\section{INTERTEXTUAL APPROACHES}

Samuel Byrskog (Professor, Lund University, Sweden): Christology and identity in an intertextual perspective: The glory of Adam in the narrative substructure of Paul's letter to the Romans (Holmberg \& Winninge 2008:1-18)

Byrskog, following the lead of Dunn (1998), particularly investigates the Adam Christology in Romans and brings to focus the notion of 'being the image of God', something which for him is at the periphery of scholarly discussion. He argues, however, that this 'is a concept that unites an understanding of Christ with an understanding of human beings and what Christ is for them, and it epitomizes Christology as a part of identity formation' (Holmberg \& Winninge 2008:1).

Using the method of intertextuality, Byrskog argues for the existence of a narrative substructure in Romans that holds the allusions (Rm 1:18-32; 3:23; 7:7-11; 8:19-22) and explicit references to Adam (Rm 5:12-21) in Romans together, which for him will open up avenues to a more dynamic thinking about Christology and identity. Byrskog acknowledges the problematic nature of intertextuality but defines his approach as 'inherently historical' and informed by theories of social (or collective) memory and orality. Following Esler (2003), Byrskog states that Paul's reinterpretation of scripture requires an understanding of social (more than literary) processes, that is, the function of collective memory whereby past prototypes are used to negotiate social identity, as well as taking into consideration the way the text is read or heard. This approach is further qualified by seeing the text as an intervention into a cultural system of other texts that condition its meaning.

In theories of the oral character of a text, the text is a web of meaning and meaning-effects that depend on the cultural signs encoded in the text and that condition the experience of it during and after the performance. To the extent that it contains traces of a cultural system of other written and oral texts, it is a reservoir of collective memory and affects the hearers' negotiation of how they remember the past socially and construe their social identity.

And so the letter to the Romans can be seen as 'an epistolary echo-chamber of remembered inter-texts', making them 'resonate' and producing meaning effects to whom it was performed orally.

After giving a very condensed outline of his methodology, Byrskog investigates Romans 1:23; 2:23; and 3:23. Romans 3:21-31 forms an inclusio with 1:23, which seen together deals with the present state of humankind inherited from Adam: all have sinned and fall short of God's glory. Byrskog identifies 
LXX Psalm 105:20, Jeremiah 2:11, Deuteronomy 4:16-18, The Life of Adam and Eve (20:2; 21:6; 33:5; 35:2), Philo's De Virtutibus 203-205, Wisdom 2:23-24 and Jubilees 3:17-31 as intertexts. The intertextual echoes reach a climax in Romans 3:23 with the emphatic 'all', reflecting the current situation of all men and women.

Romans 5-8, however, describes the way to glory. In Romans $5: 2,12-21$, Paul begins to christologise the intertextual concept of Adam's glory. At first, he encourages the hearers/readers in $5: 2$ to boast in their hope of sharing God's glory, which should not surprise us as Paul soon expounds the relationship between Adam and Christ in 5:12-21. The future life, as a result of Christ's

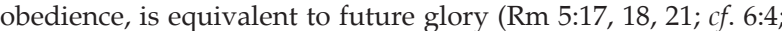
$8: 18,21)$

Romans 7:7-13, the next pericope under investigation, reads like a commentary on 5:13-14, which explains that sin was in the world before the Law and that death reigned from Adam to Moses. The ' $\mathrm{I}$ ' that experienced death in Chapter 7 resembles Adam, and the transgression of Adam (Rm 5:12-21) Paul defines in Chapter 7 as 'covetousness', which is similar to The Life of Adam and Eve (19:3). Romans 8:18-20 in turn deals with the future and climatic glory of believers themselves ( $c f .2$ Cor 3:18; $4: 4)$, which means they will be conformed to the image of God's son. Byrskog then looks at the role of Christology in identity formation. He explains as follows:

Looking at the Adam Christology from the perspective of intertextuality and social memory...it emerges as an unfolding story which interacts with other similar stories and mnemonically negotiates meaning and identity to the hearers/ readers.... Identities are projects and practices... and emerge from the ways we are positioned by and position ourselves in the narratives of the past.

(Holmberg \& Winninge 2008:16, emphasis original)

In this way, with Adam functioning as a prototype of fallen humanity and the resurrected Christ, Christology is dynamic, not merely propositional, for believers are invited into the story of Christ. Indeed, Adam Christology can be extended to dealing with human destiny at large (being God's images), the unity and restoration of humanity and fellowship with God. It can serve to react to contemporary problems as well as contribute to dialogue between various ethnic and religious groups (ibid. 2008:16-18).

Certainly, Byrskog's emphasis on the role of Christology in the formation of identity is to be welcomed; the attention he brings to the role of Adam in the narrative substructure of Romans is also persuasive. The question can be raised whether the sophisticated use of intertextuality is applicable across the board, but more about this will be said below.

\section{Per Jarle Bekken (Associate Professor, Oslo University College, Norway): The controversy on self-testimony according to John 5:31-40; 8:12-20 and Philo, Legum Allegoriae III.205-208 (Holmberg \& Winninge 2008:19-42)}

Bekken's chapter aims to investigate the controversy around Jesus' self-testimony in John (5:31-40; 8:12-20) in light of 'Jewish' forensic data, especially Philo's treatise Legum Allegoriae (3.205208). He argues that John represents a Christian version about the controversy of self-testimony that probably existed among 'Jews' of Alexandria.

Specifically, the view represented by Philo, that only God was capable of giving self-authenticating testimony, supplies a Jewish context for the point made by the Evangelist that Jesus could testify to himself because of his divine origin.

(Holmberg \& Winninge 2008:20)

Bekken then gives an outline of Leg. 3.205-208 within its literary context, his focus being on Philo's paraphrasing exegesis of the words 'By myself I have sworn' (Gn 22:16). Philo, in the form of answers and questions, speaks against objections that deny that anyone can give witness on his own behalf. God can. This is followed by a similar investigation for the pericopes in John, with 5:37 and 8:13 in need of special attention. By doing a survey of secondary literature (Holmberg \& Winninge 2008:25-30) Bekken satisfies himself that Philo can be used to illuminate Jesus' exceptional identity as revealed in the two pericopes.

A more detailed comparison between John and Philo then follows, in which Bekken points to various but previously neglected points of similarity. For example, both Philo and John used 'questions and answers' as a literary or rhetorical device, which was typical of learned 'Jewish' settings, and in both the contrast between divine and human testimony is found. There is also the epistemological argument of Jesus having knowledge of his (divine) origin and where he is going (Jn 8:14; cf. Leg. 3.205206)

This controversy about biblical laws of testimony served to investigate how the Christian community formed a 'high Christology' in its conflict with 'early Judaism'.

In the Gospel of John, the distinction between the human and the earthly level, on the one hand, and the divine and heavenly level, on the other hand, is apparent in the conflicts between Jesus and his interlocutors.

(Holmberg \& Winninge 2008:41)

Jesus' adversaries misunderstood the divine and heavenly relationships involved in Jesus' teaching and activities, and so it becomes a matter of contrasting human and divine perspectives, whereby some believers came to see Jesus as 'equal to God'.

\section{Tobias Hägerland (PhD candidate, Göteborg University, Sweden): Rituals of (ex-)communication and identity: 1 Corinthians 5 and 4Q266 11; 4Q270 7 (Holmberg \& Winninge 2008:43-60)}

1 Corinthians 5:1-13, one of the earliest acts of 'excommunication' in Christianity is investigated in light of 4Q266 11 and 4Q270 7, which Hägerland suggests both articulate and cultivate Paul's self-understanding while also reinforcing some identity aspects of Paul's addressees. He also claims that some 'remarkable parallels' in wording and content have gone unnoticed, which constitute the first part of his study. The second part turns attention to how the ritual of excommunication affects the identity of the church, as well as Paul's understanding of his own mission to and relationship with the Corinthians.

The parallels (Holmberg \& Winninge 2008:45-52) that Hägerland brings to light focus on the report of the offence, repentance, judgement, the role of the assembly and the consequence of expulsion. Despite noting the differences, the similarities convince him that Paul was indirectly influenced by Qumran. So what identity is therefore expressed by the Pauline ritual? The points of similarity between Paul and Qumran suggest that both saw the community and God's realm as identical. Expulsion is equated with separation from the spiritual life, outside of which there exists no forgiveness of sins. The concern is to preserve the purity and holiness of the collective and so contact with the expelled member must be avoided. What sets the two communities apart, however, is that the Corinthians were convinced that they lived in the messianic age while the Qumranites were still looking forward to the coming of the Anointed One(s) (ibid. 2008:53-56).

The identity of Paul reveals that like Ezra and the mebaqqer of Qumran, he considers himself as a person with authority. He claims jurisdiction over the church for which he can also lay down disciplinary rulings but is distinctive in that his rule is charismatic since Paul asserts his authority 'in spirit' (being physically absent) and so testifies to a prophetic selfunderstanding. Paul labels himself primarily as apostle, yet he sees 'himself as invested with unchallengeable prophetic authority' (ibid. 2008:59). 


\section{Some comments on intertextuality}

Intertextuality has to do with direct quotations, allusions or echoes and fragments of earlier texts (especially the Tanak) used in new ones. It also concerns, amongst other things, the issue of availability of texts to both authors and addressees ( $c f$. Hays 1989). From this several potential problems in the above articles arise. Taking into consideration that in agrarian societies only about $2-4 \%$ of the population was literate (Rohrbaugh 2008:143$145)$, one can ask how many people in Rome were familiar with the intertexts cited by Byrskog concerning Adam. How many in the Johannine community were familiar with the writings of Philo? Perhaps a few would catch the literary interrelationships, but for the vast majority these would have been lost. Hägerland's study is further complicated by the question whether indirect influence can really qualify as intertextuality. This is not to deny that the Romans were familiar with the story of Adam, or the Johannine community with controversies in Alexandria, or Paul with practices at Qumran (it is doubtful that the Corinthians themselves were familiar with these). But the arguments of intertextuality presented here are more relevant to those who could afford the luxury of reading and writing in antiquity. Byrskog is on the right track by bringing attention to the role of collective memory in an oral setting. His emphasis, however, is on remembered intertexts. The point is, those whom these authors addressed would have negotiated their identity not so much from texts as from memory, which begs the question, how much did they know and what did they remember? In the final analysis, the sophisticated use of intertextuality, as proposed here, is perhaps a more useful and secure methodology in the study of authors themselves (the literate few) and in studies of analogy and comparison in contemporary theology. As a methodology for the identity formation of the hoi polloi it is less secure. The methodological approaches taken here need revision and further clarification in terms of their applicability to the various persons and their social locations as encountered in the New Testament.

\section{LITERARY (AND SOCIAL IDENTITY) APPROACHES}

\section{Judith M. Lieu (Lady Margaret's Professor of Divinity, Cambridge University, UK): Literary strategies of personification (Holmberg \& Winninge 2008:61-78)}

Lieu investigates how personification can function as a strategy of identification. Referring to the variegated nature of personification and the various ways it was defined in antiquity (ibid. 2008:61-63), she discusses the following forms that can be encountered in the biblical and postbiblical tradition:

Inanimate objects and abstracts: When it comes to treating inanimate or abstract things as sentient beings, one common form in the ancient world occurs when worship is directed to natural or geographical features or to abstract ideas (e.g. Is 49:13; Ps 85:10-11; Rm 8:35; Gal 3:24). Especially Paul's personification of $\sin (\mathrm{Rm} 5-7)$ establishes relational activities involving human participants, 'and so they create a sense of unity and communication between personified subject and human object. The cumulative effect across these chapters is to set readers on a stage that is peopled by multiple forces, creating illusions of presence' (Holmberg \& Winninge 2008:65, emphasis original). This is mirrored in Romans 8:19, 22-23, where believers groan alongside creation, and so creates a common cause and a place where believers can position themselves.

Lieu also discusses the ancient topos of virtue and vice encountered as women, which was also taken up in later Christian discourse. A subset of this is the personification of Wisdom (hokhmah; Sophia) as seen in Proverbs 8-9 and Wisdom 7:22-30; 10-11. Lieu explains that here:

wisdom functions as the personification of culturally appropriate norms and values; she becomes the means by which the distinctive character of the people within a wider world can be explored and maintained (Sir 6:18-31), while the contrast with or opposition to folly, also personified, helps draw the boundaries that define the identity of the community (Prov 7:4-23; 9:13-18; cf. 4Q184, 185). Yet as one who encounters and addresses the individual she similarly inspires imitation or internalisation (Wis 6:12-25; Sir 38:34-39:11; 51:13-30).

(Holmberg \& Winninge 2008:68)

The state and collectives: Another ubiquitous form of personification is the representation of a state or collective as a woman. In Isaiah Zion is bereft of her children (Is 54:1; 66:7-10) and she can also say, 'The Lord has forsaken me' (Is 49:14). This type is numerous in prophetic literature (Ezk 23; 4 Ezr 10; Rv 12; etc). This topos was recognised for its rhetorical and emotional effect. In circumstances of war or pressure political rhetoric adapts itself to the imagery of the motherland, which inspires the need to protect her against despoliation and rape, in the process invoking fears of the destruction of family unity and violation of the security of home. Here personification necessarily infers the threat of the outsider, 'the other', who may intrude, while it also obscures the complexities of belonging and identity. 'If self-identity on the individual level is a continuous exercise in differentiation from the other, then such personification of the collective adopts the same binary model, the same desire to suppress internal difference in the interests of a homogenous self, opposed to the threatening other' (Holmberg \& Winninge 2008:70).

The logo: Lieu also looks at the contemporary usage of logos, which communicate the identity of institutions. Perhaps we find a similar example on the Judaea capta coins minted by the Romans, which with other examples claim personal qualities for the collective.

Abstracts once more: Here we find the personification not of something inanimate but of an individual, whereby (s)he represents a particular characteristic (e.g. ruthlessness, gentleness or wickedness). Philo used Abraham's journeys not only as those of the man but also of the 'virtue-loving soul' (On the Life of Abraham 14.62-18.88). Here personification becomes an interpretive strategy, not a compositional one, whereby, for example, it can be debated whether 'the Jews' in John's gospel are intentionally presented as the personification of unbelief or whether it is created by the interpreter (Holmberg \& Winninge 2008:72).

The individual and the collective: An individual is presented as the personification of a collective or a part of it, for example Nelson Mandela as an icon of the struggle against apartheid or the Beloved Disciple as the personification of the Johannine community.

Shifting personifications: This deals with postmodern games with personification, for example avatars of self in cyberspace.

Lieu points to the fact that the vast majority of personifications in the ancient world are feminine. Here the cultural status of women plays a role as the 'female combines the unstable, the malleable, and the undesirable' (ibid. 2008:74). Also analysing how rather than why most personifications are female, she identifies four particular issues: personification as paired women (e.g. virtue vs. vice; Wisdom vs. Folly in Proverbs), the threat of the seductress (the danger of negative female figures, such as that used in Revelation to represent the dangers of heresy and apostasy), the male viewer (the viewer and normative identity are constructed as male) and the manipulation of gender (independent femininity is suppressed or women's sexuality is repudiated).

Lieu's wide-ranging study highlights identity formation on various levels. Perhaps her study is too wide in its scope, but she demonstrates how personification variously brings people into relationship with virtues and vices, propaganda and collectives, which also define the self, a sense of belonging and boundaries visà-vis the 'other'. This relationship highlights positive or negative 
characteristics and evokes emotions, feelings of vulnerability or (dis)association, where people in texts acquire identities (and therefore attributes) predominantly using the more malleable discourse of feminine gender. At the same time it was always approached from the 'normative' identity of 'maleness'. As can be seen, Lieu's contribution can also be useful for further studies on gender.

\section{Lauri Thurén (Professor, Joensuu University, Finland): The antagonists - rhetorically marginalised identities in the New Testament (Holmberg \& Winninge 2008:79-96)}

Thurén investigates how the 'antagonists', especially in the New Testament epistles, have 'unjustly' been marginalised Understanding that we are dealing with conflict-orientated documents, we see that New Testament authors appear to be constantly at odds with persons or groups. Thurén argues that four essential problems exist when studying opposition in the New Testament (ibid. 2008:81-94).

Firstly, there exists a basic mistrust of the opponents' description, since their identification in scholarly work is too numerous and they have mutually exclusive attributes. A review is done of how opponents are described in Galatians, Colossians, 2 Timothy, Jude and 2 Peter, all of which contain contradictory claims about who they were. Thurén summarises that 'either too much or too little information about the antagonists is provided, so that it is impossible to create a solid portrayal of them.... The New Testament epistles were not written in order to provide modern readers with information about the adversaries' (ibid. 2008:85), which would have been known to their recipients.

Secondly, the antagonists are described in stereotypical fashion (intruders, lying hypocrites, filled with moral depravity, etc.), which was a standard rhetorical topos (vituperatio). We cannot obtain neutral data about them, thus the nature of heavy rhetoric must be understood. It does not serve to introduce the antagonists, their behaviour or their reasoning but instead serves to disassociate them from the recipients.

Thirdly, mirror reading, normally used to identify the opponents, must be abandoned since we cannot know what is based on fact and what is mere rhetoric. Thurén argues for a process of derhetorising, whereby we can go 'behind' rhetorical polemics, where, for example, 'if we find among classical stereotyped accusations some atypical, surprising claims, they could convey a glimpse of the actual situation' (ibid. 2008:88-89).

Fourthly, Thurén goes on to question the actual existence of the antagonists. They 'represent opposite values, alternative thinking or inappropriate behavior' (ibid. 2008:90, emphasis orginal) For example, in Romans Paul creates an opponent (Rm 3:3-8; $6: 1$ ). In Galatians, however, Paul counters opponents planning or preaching circumcision, yet we do not know whether they represented the theology Paul opposed. So what was the function of these 'straw men', Thurén asks? They were introduced due to rhetorical praxis, to present complicated theology to an illiterate audience, which required the personification of real or imaginary opponents representing abstract ideas. So the technique of prosopopoiia is employed whereby theoretical views are presented as if they were advocated by real people. Paul's contrast between righteousness through the Law and through faith/Christ did not require that somebody actually represented the former.

Paul presents such a sharp contrast and absolute version of "legalistic" soteriology that it exceeds any contemporary Jewish text. Based on our current knowledge, it is plausible that it was composed by Paul himself.

(Holmberg \& Winninge 2008:92)

Thurén goes on to suggest that many of the antagonists we encounter in the Pauline texts are fictional imaginations created by Paul. But here one can get confused for in other places it is stated that they did have some contact with real historical people (ibid. 2008:92) or the antagonists 'lived among the addressees and were well known to them' (ibid. 2008:86) and the original antagonists 'were presumably distressed to hear the texts' (ibid. 2008:95). Paul 'invariably give [sic] a wrong impression of those individuals, at least in our eyes. They were marginalized without justification' (ibid. 2008:92). How much Paul or other authors were merely doing theology or opposed real antagonists is left unclear. The emphasis, however, appears to be on the former. So why did Paul create these people? According to Thurén it was to help Paul formulate his own theological reasoning. 'Reaction to social challenges is a too simple explanation of his theological thinking'. Paul was driven by his passion for theological issues, and his 'theological opponent, the real antagonist in Galatians, was Paul himself' (ibid. 2008:94), as was the case with many others.

Thurén appears to reject the New Perspective on Paul (cf. Dunn 2007) because the apostle opposed an absolute version of 'legalistic' soteriology (something he perhaps created himself) and he did not address social situations as such. The problem is that Paul and other New Testament authors become armchair theologians, somewhat detached from the situations faced by their congregations. Such an approach is not convincing. Another important argument against Thurén is that due to low rates of literacy, texts were orally performed ( $c f$. Horsley \& Draper 1999; Mournet 2005) and the audience was present already at the time of composition and ancient 'rhetorical practice itself ensured a strong correlation between the values and interests of the audience and the shape of the text' (Kloppenborg 2000:169). This means that composition of texts and rhetorical practices have their end users in view, not the 'internal' thoughts and struggles of authors. The latter scenario does not really allow for addressees to relate to what Paul and others were writing. Sure, the antagonists were probably the victims of rhetorical overkill but in the end the rhetorical strategy of prosopopoiia, in this case the invention of fictional marginalised opponents in the New Testament, is yet to be convincingly demonstrated.

Thomas Kazen (Associate Professor, Stockholm School of Theology, Sweden): Son of Man and early Christian identity formation (Holmberg \& Winninge 2008:97-122)

Kazen engages with the 'embarrassing' lack of consensus when interpreting the Son of Man in the New Testament and builds on previous work in which he argued that the historical Jesus used the term as a 'collective' expression and used it for kingdom imagery, using it as a symbol 'or an embodiment of the faithful remnant' as in Daniel (Holmberg \& Winninge 2008:99). In the present study Kazen applies this insight to the significance of the Son of Man for identity formation, as the various writings of the New Testament applied it to Jesus as an individual redeemer figure, yet retaining it as a means of Christian collective identity formation.

Kazen briefly mentions the insights of social psychology into social identity, being dependent on the work of Henri Tajfel (1978; 1981) and John C. Turner (1987). Instead of focusing on the individual and his/her relationship to a group, he is more interested in group identity and generalised forms of behaviour and beliefs. He retains, however, Tajfel's (1981:256) observation that group membership, especially when seen as disadvantageous, will be retained if associated with important values that contribute towards a positive self-image. Thus, unwelcome features can be justified through reinterpretation or the situation can be accepted as it is by the group and the group can engage in social action to make desirable changes. According to Kazen, the Son of Man typology facilitates both of these categories (Holmberg \& Winninge 2008:101).

Kazen proceeds by giving an overview of the Son of Man in Daniel, 1 Enoch and the New Testament. The figure in Daniel 7 is well suited to group identity formation as the group members, although crushed, hope for vindication and the Son of Man 
imagery confirms them as the true people of Israel as well as the values they hold. Their low status as opposed to the 'Hellenisers' is no disadvantage and will one day be reversed when they, the faithful and observant, will be rewarded. In 1 Enoch (Parables, chapters 37-71), which is of uncertain dating, the concern is similarly with the identity, character and fate of the community and is not only focused on the messiah figure. The 'Righteous / Chosen One' and 'Son of Man' functions as a heavenly type for his earthly counterpart, who similarly functions to invert low status. Here he still functions as a collective symbol although he is becoming more individualised.

According to Kazen, the same pattern emerges in $\mathrm{Q}$ and Mark but to a lesser extent in Luke-Acts and Matthew. Especially in $\mathrm{Q}$ and Mark, aspects of suffering, judgement, itinerant lifestyle, serving, poverty and being a faithful remnant are variously attributable to the identity of Jesus and his followers, yet future vindication will accompany value and power reversal. In Mark it is likely that the Son of Man, being intimately connected to Jesus, functions also as a role model for the community. In LukeActs the Son of Man is not developed and hardly plays any role in group identity. In Matthew, Jesus as an individual redeemer figure is consistently identified with the Son of Man and also appears to be of minimal significance for identity formation.

Kazen lastly investigates the writings of Paul, in which the Son of Man never appears explicitly. Presupposing that usage of the Son of Man at this stage was in a state of flux yet more associated with a collective symbol of a future kingdom and not readily accessible to Paul's Hellenistic congregations, what we rather find is the content of a collective interpretation, similar to that found in $\mathrm{Q}$ and Mark, but without the Son of Man imagery as vehicle. This is evident in Paul's 'theology of suffering and eschatological redemption, and in his particular participatory language' (ibid. 2008:118). This is juxtaposed, however, by Jesus' appearing as an eschatological redeemer figure, and he can be seen as the foremost of a larger group of kingdom representatives.

The crux of Kazen's investigation can be represented by the following words drawn from his conclusion and that are especially relevant to early recipients of Daniel, Q and Mark:

Son of Man imagery particularly contributed to Jewish apocalyptic and early Christian identity-formation with regards to attitudes to suffering and persecution. By identifying with the Son of Man, suffering and hardship could be viewed as a necessary prelude to eschatological vindication, including a reversal of status and power. The expectation of future vindication, even taking part in divine judgment, compensated for present lack of position and power. The traditional value scale could thus be reversed; honour could be attributed to servanthood, poverty, weakness and death.

(ibid. 2008:121)

One could put forward the argument that individualisation of the Son of Man figure is already present, for example in $\mathrm{Q}$ (cf. Cromhout 2007:313-315), but on the whole the followers of Jesus certainly identified with the Son of Man and his pattern of suffering and vindication. Kazen successfully employs social identity theory to illuminate how the 'negative' identity of Jesus and his followers was inverted to embody positive values. Present suffering, when viewed from the eschatological community of the Son of Man, acquires attractive theological (and social) meaning and becomes an identity that anticipates divine vindication.

Raimo Hakola (PhD, postdoctoral researcher, Helsinki University, Finland): Social identity and a stereotype in the making: The Pharisees as hypocrites in Matthew 23 (Holmberg \& Winninge 2008:123-140)

Hakola uses insights from social psychology to explain how Matthew's portrait of the Pharisees, especially their representation as hypocrites in Chapter 23, functions in the gospel.
Hakola presents at first an overview of scholarly responses to Matthew 23 and argues that Christian theology, and scholars in general, traditionally gave a distorted view of real-life Pharisees. This changed somewhat with the work of E.P. Sanders (1977), and it has become increasingly common to situate 'Matthew in the context of a conflict between Matthew's Jewish-Christian community and the post-70 rabbinic movement' (Holmberg \& Winninge 2008:127), which is claiming the leadership of the Jewish communities. Yet if one places Matthew's attack within the context of ancient rhetoric, attributes such as vice and vainglory, love of money/pleasure and hypocrisy were standard categories applied to opponents. But some questions remain. Many scholars have questioned the influence and power of the early rabbinic movement, which raises the question why Matthew chooses the Pharisees (and scribes) in particular as targets, something that Hakola proposes could be illuminated by the use of social psychological theories (ibid. 2008:129).

Hakola initially refers to the work of Saldarini and Ulrich Luz. Citing Saldarini (1992:659), Hakola writes as follows: 'From a sociological point of view, vilification and misrepresentation of the opposition can serve to establish the identity and boundaries of the polemicist's group and weaken the power and attraction of the opposing group' (Holmberg \& Winninge 2008:130). This insight of vilification to help establish group identity Hakola finds useful, as well as Ulrich Luz (2005) in his use of social psychology, which also puts emphasis on the importance of defining boundaries against outsiders and to maintain and strengthen one's own identity and group cohesion. In addition, outward verbal aggression is also a way of coping with failure and suffering, and outward prejudice increases the stability of the in-group. Hakola then follows Saldarini and Luz's lead and focuses on the social identity theory of intergroup relations, as developed by Henri Tajfel and John Turner.

Tajfel (1981) determined that members tend to favour the ingroup and the individual's concept of his or her membership of a social group and the value and emotional significance attached thereto. Social identity, as investigated by Turner (1987) (i.e. selfcategorisation theory), observed that social categorisation, that is, how we define ourselves in relation to others, is a fundamental aspect of group behaviour. It is a cognitive grouping process that transforms differences into similarities for members of the same group, while at the same time various groups are seen as more different from each other than what they really are. Both Tajfel and Turner (1979) also explain that the mere recognition of belonging to two different groups triggers intergroup discrimination and that the need for social differentiation is met by creating differences (and stereotypes) or enhancing those that already exist. 'Therefore, the polarization of attitudes between an in-group and its pertinent out-groups', Hakola argues, 'does not by itself provide evidence for the ongoing real-life conflict between the groups in question' (Holmberg \& Winninge 2008:133).

Hakola then applies his approach to Matthew 23, in which the conflict between Jesus and his opponents, or the idealised ingroup and denounced out-group, 'is an example of extreme and polarized group prototypes typical of the process of social categorization' (ibid. 2008:134). As it turns out, however, Matthew 23 is not an example of intergroup conflict but rather depicts a conflict of consciousness within the group, or cognitive dissonance. It relates to the problem of obedience to the Torah in the community and a dispute in terms of its significance for daily life. According to Hakola there 'were major ambiguities in Matthew's understanding of the Torah', and this was 'the main source for arousal of cognitive dissonance among the members of his community' (ibid. 2008:138). What Hakola proposes is the following: The way to reduce the dissonance between the emphasis on keeping the Law and

the more liberal religious practice of the community was to externalize the dissonance by making it a main characteristic of 
those who represent the most virulent defenders of the Law in Matthew's gospel, namely the Pharisees.

So the beliefs within the community are not represented as dissonant but are transferred to the Pharisees, portrayed as hypocritical teachers. Thus the conflict actually reflects the ambiguous self-understanding of the Matthean community.

Hakola presents an ingenious approach to resolve two related problems: the vociferous nature of Matthew's anti-Pharisee polemic and why the Pharisees, a social group who exercised little influence or leadership, were targeted. Hakola seeks to address the cognitive dissonance within the community with regard to observance of the Torah and why the scrupulous Pharisees were targeted for its externalisation. The result is worth looking at, but the approach is susceptible to potential problems. Firstly, was there cognitive dissonance within the Matthean community? Did they not see themselves as living faithfully to the Torah, as a continuation of the Judean way of life, and that Jesus brought the true interpretation of the Law (cf.; Saldarini 1994; Sim 1998)? If there were ambiguities they need to be properly demonstrated. Second, Tajfel and Turner's ad hoc experiments and conclusions were derived from face-to-face intergroup settings. Their results were also subsequently questioned, and it was demonstrated that in-group bias and intergroup conflict/stereotyping are not inevitable results of group membership but are more typical within a context of collectivism and competition (Brown 1995; 2001). For Hakola's approach to be more convincing, therefore, and to give a proper context for the state of cognitive dissonance within Matthew's community, he needs to assume a degree of ongoing real-life conflict between the Matthean community and the Pharisees. It is more plausible that both social categorisation (i.e. stereotyping) and the state of cognitive dissonance accepting for the moment that it existed - were exacerbated by regular and intense conflict with the scrupulous Pharisees.

Rikard Roitto (PhD Candidate, Linköping University, Sweden): Acts as a Christ-believer, as a household member or as both? - A cognitive perspective on the relationship between the social identity in Christ and household identities in Pauline and Deutero-Pauline texts (Holmberg \& Winninge 2008:141-162)

Roitto investigates how household identities stand in conflict with or are seen as a subcategory of and compatible with identity in Christ, using the insights of self-categorisation theory and cognitive psychology.

According to various sources on social identity and cognition, categorisation of people in contrast with others leads to prototypes and is also ordered into hierarchies. At the top are more inclusive categories and social identities as compared to those 'below' and a subcategory inherits the properties of the superior category. People also choose between social identities, but where they are not hierarchically subordinated to one another, identification with any one of them in the same situation becomes more difficult. There is, however, the usual tendency to identify with one and to suppress the other (Holmberg \& Winninge 2008:142-144).

Roitto then gives a brief overview of the nature of social identities in the first-century Mediterranean world. He observes that it was collectivist and notes the importance of the household and kinship hierarchy, yet this was complicated by the possibilities of social identities offered in the cities.

Religious groups (Christ-believers, mystic cults, Pharisees etc.), burial societies, schools, philosophical sects ..., associations based on occupation, patron-client-networks etc. provided an ambiguous web of possibilities for social identification in any given situation.

(ibid. 2008:146)
In a situation like this the individual must make decisions as to what identity to adopt in various circumstances, forming a pattern that does not coincide with the family structure. It is in such a situation that the Pauline communities found themselves.

The focus then shifts to Paul's writings (1 Cor 7) in which he, inter alia, resolves the potential conflict between identity as spouse and identity in Christ, the latter being the most important one. The same is true of the situation of slaves, and in the letter to Philemon he is asked to allow his identity in Christ to take priority over his identity as master. Overall Paul sees identities in Christ and identities as spouses, slaves and masters as separate, not as hierarchically subordinate, and as the cause for potential conflict. The formulation in Galatians 3:28 'probably reflects the social experience that these social identities could be temporarily left aside in the community of Christ-believers' (Holmberg \& Winninge 2008:148). Paul's approach, however, caused problems and identity conflicts, which the later DeuteroPauline writings needed to address (ibid. 2008:146-149). This begs the question: What were the root causes of these identity shifts in Paul's communities? Was it Paul and the radical nature of his gospel, or was it something that just happened by itself? This matter is left unclear.

In the Deutero-Pauline letters, Roitto explains, household members are treated differently. The household codes in Colossians 3:18-4:1 and Ephesians 5:22-6:9 demonstrate that household identities are subcategories of the identity in Christ. Behaviour appropriate to these identities (husband-wife, master-slave) is motivated on the basis of the ideals of being a prototypical Christ-believer ( $\mathrm{Col}$ ) or by way of analogy whereby knowledge from one cognitive domain or pattern, something shared by people within cultures, is transferred to another (Eph, viz. the example of Christ or submission to Christ), and so the subordinate category inherits the characteristics of the superior category.

In 1 Timothy 3:1-13 the transfer of norms goes in the opposite direction, and competence in the (subordinate) household becomes the prerequisite for competence as a leader in the congregation. It therefore represents the most complete integration of household identities with identity in Christ since household duties give status before God and the congregation. This kind of integration is found to a lesser extend in Titus 2:110 but here there is also no conflict between these two spheres of identity (ibid. 2008:151-152). Roitto also provides a useful diagram of how these identities work in Paul and the DeuteroPauline writings on p. 152.

The investigation is closed by a cognitive and historical analysis of why these spheres of identity were treated so differently (ibid. 2008:153-160). Roitto proposes that written texts articulate a cognitive representation of a lived social reality. If we then look at the chronological development within the Christ-movement (1 Cor \& Phlmn; Col \& Eph; 1 Tim \& Titus), at the early stage, as outlined above, for Paul himself identity in Christ and household identities were seen as separate. For Roitto eschatological, missionary or gender explanations are insufficient, and we need to turn our attention to the social reality behind the matter, which he suggests was that individuals, not entire households, more often converted to the Christ-movement in Paul's time. As time progressed, however, it seems to have become increasingly more common for several members to become Christ-believers (e.g. 1 Tim 6:2). This also explains why influential members, or the heads of households, saw it as functional to make household identities subordinate to identity in Christ and exerted their influence on the congregations accordingly.

Roitto's argument that for Paul identity in Christ and household identities were separate but not hierarchically subordinated is in need of further explanation. Are the implications limited to household identities becoming irrelevant only in a 'religious' 
setting? Were participants not perhaps seen as 'equals', applicable to all domains of life (cf. Crossan \& Reed 2004:74-75, $111)$ ? Otherwise his presentation of identities outlined here is interesting and thoughtful, assuming that it is just a matter of values and interests being shared between texts and addressees. But perhaps this does not explain everything. In the final analysis it appears to make Paul's gospel, at least some of its radical social aspects, more influenced by existing socio-religious realities rather than being an inherent part of the gospel itself. Is it not equally plausible that Paul was writing from the perspective of his gospel, in which identity in Christ was everything, rather than articulating a cognitive representation of a lived social reality? Moreover, were the Deutero-Pauline writings not addressing a situation of identity conflict caused by Paul's gospel (as suggested by Roitto himself)? If not, Paul's gospel in its very essence and ensuing social consequences is hardly as revolutionary as it appears on the surface. The problem that Roitto needs to look at is what the balance is between written texts articulating a cognitive representation of lived social realities and texts functioning as rhetorical means of instruction and persuasion to transform or reinforce change in lived social realities (cf. Tuckett 1996:82-92).

\section{GENDER STUDIES}

\section{Halvor Moxnes (Professor, Oslo University, Norway): Body, gender and social space: Dilemmas in constructing early Christian identities (Holmberg \& Winninge 2008:163-182)}

What does it mean to be a man or woman with bodily needs, who is involved in social relationships and mostly in the nonelite portion of society in the Eastern Mediterranean? Moxnes (1996) suggests an integrated approach to gender and space studies, since bodies

are always gendered and always placed. They represent men and women, and they are placed in biological, social and cosmological hierarchies, as well as in spaces that have different characters: domestic, public, ritual and cultic.

(Holmberg \& Winninge 2008:165)

Moxnes notes that initial studies on the body have not been concerned with concrete, physical bodies or their relationship to gender, but

we may now speak of early Christian gender studies that are concerned, not only with the social roles and histories of women and men, but with the formation and the upholding of their identities.

(ibid. 2008:166)

This is complemented by the recent studies of space, which denotes not merely physical settings but social, ideological and mental places of identity. 'The issues we shall look at', Moxnes then explains,

are the relationship between sexual ethics and bodies in 1 Corinthians 6:12-20; the question of voluntary castration in Matthew 19:12 and the reaction to involuntary pain suffered by slave's [sic] bodies in 1 Peter 2:18-25.

(ibid. 2008:168)

In 1 Corinthians 6:12-20 Paul commands that men in Corinth must not engage in sexual relationships with prostitutes. Paul addresses his readers as 'body' repeatedly and his concern is with relationships to the body and of the body to other bodies. Paul also views a man in that he 'is his body' (emphasis original), so here sexual ethics and male identity intersect. Moxnes explains that in the male-dominated slave societies of the Greco-Roman world prostitution was common and sexual ethics determined that the free man had sexual rights over all subordinates. But for Paul, the female prostitute becomes a threat to a man's identity. 'To be joined' to a prostitute is compared with 'to be joined' to Christ, where in both cases a man enters into a union that determines his identity. So Paul differs from the moral philosophers who stated that the free man must be in control of his own body. Believers' bodies are members of Christ (1 Cor 6:15) and were bought at a price (1 Cor 6:19-20). Paul destabilises the male identity of free men, those who think that they are in command of their own bodies, as he compares them with slaves whose bodies belong to a slave master.

The body is not within a man's own control, it lalong with his identity] is determined by the relationship into which it enters.... The bodies of Christian men are addressed as members of the dead and resurrected body of Christ, which they have become by baptism.... It is this unity that is threatened by sexual unions with prostitutes since such unions destroy this Christian cosmology.

(Holmberg \& Winninge 2008:171)

The matter of eunuchs, mentioned in Matthew 19:12, is investigated next. Moxnes notes that Christian writers (except Paul, as mentioned above) of late antiquity shared the very strong views on masculinity of the Roman elite, which placed emphasis on self-control and control of the body and which also influenced the interpretation of Scripture.

The conviction that renunciation of sexuality required male selfcontrol and steadfastness also determined the paradigm of the interpretation of one of the most difficult sayings of Jesus, the word about eunuchs in Matt. 19:12.

(ibid. 2008:172)

According to Moxnes, most interpreters of antiquity, apart from Tertullian, rejected the possibility that Jesus' statement meant genuine physical castration and thought that it was cast more along the typical lines of chastity, the ideals of asceticism and self-control. But Moxnes suggests that Jesus' saying may be a challenge to the important value of masculinity. If we presuppose that Matthew 19:12 was a separate logion, it could be that it was a response to slander and accusations that Jesus and his followers were 'a "bunch of eunuchs"' (ibid. 2008:174); that is, they had left their households and had left behind their male roles.

Therefore, it is possible to understand this saying as Jesus taking up the accusation ... presenting the eunuch as an ideal figure for the Kingdom, even if, or just because, he did not conform to masculine role patterns.

(ibid. 2008:174)

This reading is strengthened when seeing it together with Matthew 12:13-14 that deals with children as models for kingdom membership, and together they reverse the social structure whereby adults and 'real' men had a privileged position. Moxnes therefore argues that taken together, these sayings give a picture of the Kingdom that is very different from the ideal patriarchal household. The male world, in which everybody knew their place, is turned upside down. The eunuch and the child are lifted up and into the Kingdom, which becomes an alternative to the surrounding society (ibid. 2008:175).

In 1 Peter 2:18-25 Moxnes investigates slaves' bodies and their comparison with the abused body of Christ. Noting that the Greco-Roman world was a slave society and that the word soma was a euphemism for a slave, he writes that slavery 'consists of the disempowerment of the subject and the loss of control of one's body' (ibid. 2008:176). 1 Peter 2:18-25 addresses household slaves and forms part of the larger text with instructions for household management. It encourages slaves to be submissive and endure patiently, even if beaten and subject to cruel masters, it being parallel to the abuse suffered by Christ. This deals not only with the 'inner person', but the bruised image of Christ is inscribed on the bodies of these slaves who will also share in his glory.

'In all these texts', Moxnes concludes, 'the privileged role of the free man and his position in the social hierarchy are questioned' (ibid. 2008:180), meaning their relationships to their body, their gender and social space. The participants enter into a new social space (i.e. bodily union with Christ, the Kingdom or a future space for slaves).

What we find in Moxnes's study is a deconstruction of male roles, statuses and the usual content of masculinity and therefore 
the transformation of male identity in an alternative 'space'. The exact implications, however, are left open and are not explained. Do elite males have no special status vis-à-vis other groups? In other words, are they reduced to being 'equals'? Must they slide down the scale of masculinity towards being effeminate (take on roles and statuses normally expected of women or even slaves)? Or does becoming like a child/eunuch mean that identity determined by Christ confers no traditional status whatsoever? What is the content of their 'new' identity? It would be interesting to discover Moxnes's view on these questions. Otherwise it is an appealing study, suggesting how male prerogatives were cut down to size in some of the branches of early Christianity.

\section{Frederik Ivarsson (Lic. theol., PhD candidate, Göteborg University, Sweden): A man has to do what a man has to do: Protocols of masculine sexual behaviour and 1 Corinthians 5-7 (Holmberg \& Winninge 2008:183-198)}

Ivarsson investigates 1 Corinthians 5-7 with the assumption that the main issue is not sexuality but masculinity and the behaviour of free men. Paul wants the Corinthians to expel men who are involved in porneia. In addition to this, Paul is responding to challenges to his authority, so he exhibits masculine behaviour in his argument, a trait that the Corinthians must imitate. The context in which Ivarsson wants to read Paul's argument 'is Graeco-Roman constructions of masculinity in general and norms of masculine sexual behaviour in particular' (ibid. 2008:184), something that needs to be taken into account when studying the letters of Paul. These are referred to as 'protocols', cultural ground rules or fundamental conventions generally taken for granted, which concern themselves with appearance and reputation.

Ivarsson then explains that masculine sexual behaviour is restricted by two main protocols: dominance and self-restraint. They need to be respected, at least in public, if a man wants to aspire to some status and honour. Failure to do so is a sign of effeminacy. 'A man has to do what a man has to do. And if he does not, he is womanish and "soft"' (ibid. 2008:185). The first protocol entails that a man must not be sexually dominated by anyone else; the second that he must not be dominated by his own passions and desires. These protocols were not so different from those held by 'Jewish moralists' and thus would have been shared between Paul and his gentile neighbours.

Ivarsson then turns his attention to Paul addressing the matter of porneia in 1 Corinthians 5:1-13. He does not want to speculate on its exact meaning, apart from that it is 'bad sex - sexual activities that are impure, rebellious, and humiliating. And, I would argue, a man who involves himself in porneia compromises his masculinity' (ibid. 2008:189) and so is morally and bodily corrupt.

1 Corinthians 6:9-11 receives attention next. Ivarsson notes that Jews often stereotyped gentiles (elite gentile men in particular) as effeminate. This attribute is used by Paul in 1 Corinthians 5-6, and in 5:9-13 he warns the Corinthians not to let themselves be affected by this gentile depravity. 'Effeminate male bodies belong outside the community' (ibid. 2008:191). Reading malakos as 'effeminate', when applied to a man, it refers to gender deviance, a failure of masculine gender performance. Arsenokoita Ivarsson suggests probably refers to some or other homoerotic activity. So the Corinthians have an unstable masculine status, and it depends on whether they stay in contact with Christ and the spirit.

1 Corinthians 6:12-20 deals with sin against the body. Here, according to Ivarsson, Paul mentions the first protocol of masculinity: 'I will not be dominated by anything' (1 Cor 6:12),

1.Elsewhere Moxnes explains that male roles, statuses and masculinity are deeply interconnected with the aggressive but variegated world of male honour (Moxnes 1096). Men competed with one ancther in bravery and in sexuat peromance (you). Men comper or they had one another in bravery and in sexual performance (younger men), or they had to be able to maintain the chastity of women under the control, exercise honesty and fulfill their obligations towards wife and family (older men). Male honour had to be maintained, extended or defended in various ways. entailing a refusal to be submissive to anything or to anyone. ${ }^{2}$ Yet Paul modifies this statement by saying that the body belongs to Christ and believers are members of his spiritual and powerful body. This makes them holy and spiritual, and if they remain thus, they will be raised by God's power. 'Belonging to Christ is thus the source of true masculinity' (Holmberg \& Winninge 2008:193). If a man is to penetrate a prostitute, a typical masculine thing to do, Paul argues that through this union a man loses control and is dominated by her, robbing him of his masculinity. Porneia emasculates and destroys the male body, and the guilty disqualify themselves from membership of the congregation of God.

Lastly, Ivarsson investigates the issue of marriage in 1 Corinthians 7:1-40. After exposing the Corinthian men to their vulnerability to porneia and its consequences, Paul turns to the alternatives: sexual abstinence or sex with their wives. The former is preferable but the latter is acceptable, even if through a concession, and here Paul's emphasis seems to be that every man is to have his own woman. Paul also for the first time has something to say about the behaviour of woman, as 'each woman should have her own man'. He also stresses the equa standing of husband and wife and their mutual obligations and rights, but since marriage was not an equal and symmetrical relationship (men did not have any sexual duties to their wives and wives could not deny the rights of their husbands), 'the masculinity of married men starts to crumble under the weight of Paul's rhetoric' (ibid. 2008:196). Paul even states that the wife has authority over the body of her husband! 'The first protocol of masculinity, dominance, is thus incompatible with married life' (ibid. 2008:196). This is due to the men's lack of self-control, standing in contrast to Paul, who in his own writing appears as the only example of true masculinity.

The overall result is that when Paul's instructions are read in light of Graeco-Roman protocols of masculinity and masculine sexual behaviour, new perspectives come to the fore. It turns out to be quite humiliating for the Corinthian men, as they do not demonstrate true masculinity, that is, self-restraint and sexual integrity. What we find is a coherent reading of Paul's argument against the vulnerability of gentile effeminancy. Their shortcomings in discipline and self-restraint force Paul to recommend some special measures: They must accept the relative humiliation of being sexually submissive to their wives in order to avoid the absolute humiliation of porneia (ibid. 2008:198).

In this study masculinity is both deconstructed and redefined. This stands in contrast with Moxnes's study that questions the need for its continued existence. Here any form of dominance is rejected, while 'true masculinity' points to bodily integrity, selfrestraint, being sexually submissive to your wife, recognising equal standing within marriage and belonging to Christ. A man can still remain a man, albeit a Christian one. Ivarsson's identification of a coherent argument in 1 Corinthians 5-7, specifically using gender studies, is deserving of attention, but further studies must show whether Paul really had the ideal of 'true masculinity' in view for the Corinthian men or perhaps something else that went beyond traditional categories. Other passages (e.g. Gal 3:28; 1 Cor 11:3, 11; 14:33-36) in which Paul variously negates or reinforces gender hierarchy ( $c f$. Schüssler Fiorenza 1983) also need to be brought into the discussion, and the issue is also complicated by the question whether all the passages are authentic or later insertions. Even so, both the studies of Moxnes and Ivarsson open up new opportunities for further exploration.

Hanna Stenström (PhD, researcher at the Church of Sweden Research Unit, Uppsala, Sweden): Masculine or feminine? Male virgins in Joseph and Asenath and the Book of Revelation (Holmberg \& Winninge 2008:199-222)

In another study on gender, Stenström investigates how gender

2.One can argue, however, that it can also apply to the second protocol (selfrestraint). 
is used in Joseph and Asenath and Revelation as a strategy of identification in the Hellenistic world. In both texts characters are described as men and as parthenos/parthenoi, ${ }^{3}$ a feature that is quite unusual, and these texts are also generally accepted as the earliest examples. As a means to construct identity, gender speaks to the broadly accepted values of society, and words can be used where they are given social significance, that is, meaning far beyond the biological, parthenos being an example. Stenström performs her investigation within the context of the phenomenon of gender-bending in early Christianity. Woman were seen as needing to become like men in order to reach spiritual perfection, but the question is whether the use of the feminine word parthenos in relation to men is a matter of genderbending in the opposite direction.

Stenström explains that the ancient world did not have a polarised view of gender as is the case today but that it functioned along a gradient of relative masculinities, ranging from 'true men' (fully masculine) to 'true women' (lacking masculinity). Women can become men, and vice versa (Holmberg \& Winninge 2008:208). Masculinity was therefore always something constructed, not an inherent characteristic or a biological given. The values of honour and shame were closely connected with gender and sexuality. The preservation of masculinity necessitated the continuous defence of one's honour and rejection of everything weak and feminine. The central element of femininity on the other hand was to show concern for shame achieved through sexual exclusivity, which also implied remaining a virgin before marriage.

Although the ancient discourse on masculinity was not monolithic, a central and common characteristic was 'mastery', over oneself or of others. The era of the Roman Republic and early Empire was also a time of change in the understanding of masculinity when the Roman and Greek understandings encountered one another. 'The ideal masculinity [in the Hellenistic world] that emerged in this process was the masculinity of the responsible citizen, who exercised public virtues: peaceful qualities and acts such as self-mastery, the administration of public affairs and participation in judicial decisions' (ibid. 2008:206). In the Roman Empire, there were two dominant discourses on masculinity: First, the discourse on whether men should marry and beget children, and second, the popular discourse of sexual domination and power.

The investigation of Joseph in Joseph and Asenath leads Stenström to conclude that typical masculinity is used to reinforce 'Jewish' piety. Joseph resists the 'foreign woman', is loyal to God and as a virgin exemplifies self-control and virtue. After he marries Asenath his masculinity is further exemplified: He is sexually dominant, is a father and husband and also takes up power and responsibility in the city. But the text also deals with collective Jewish identity and deals with themes such as intermarriage and conversion. The story can also be read as ' $U s$ vs. Them', how distance can be kept or overcome. Joseph as parthenos can become

an image of how the social body of the community guards itself against the dominant culture ... the intact body of the female virgin inspires meanings such as integrity and unbroken boundaries that are transferred to a man and then the social body of the text's original audience. At the same time, Joseph is also a model to be followed for a community that accepts proselytes...

(ibid. 2008:215)

Revelation 14:1-5 is also a text about 'Us' in contrast to 'Them', but here we find a 'complex mix of femininity and masculinity' (ibid. 2008:221). On the one hand the 144000 are described as a company of men who represent masculinity; they are like soldiers but also have self-control since they do not allow themselves to be dominated by threatening women. Parthenos

3.Stenström also mentions that she uses parthenos and partheneia without translating these words because they do not necessarily have the meaning of 'virgin'. also triggers meanings of integrity and self-containment. But being described as parthenoi combined with their passivity also makes them feminine. For Stenström, various readings are possible in the text. Firstly, either the 144000 parthenoi, when approached as persons, are really masculine or when seen in relation to God they are like a passive woman in relation to her male head. Secondly, when seen as imagery, to follow the Lamb is made attractive by various images that open up many interacting meanings that can be described as feminine, as representations of an archaic masculinity and as representations of an alternative masculinity' (ibid. 2008:222). Although this may point to asceticism, Stenström does not want to speculate on what this means in practice but states that the 144000 parthenoi may be understood as 'images of a group that guards of [sic] the boundaries of its social body ...' (ibid. 2008:222).

One can appreciate Stenström's nuanced presentation of gender and masculinity and that in the context of antiquity gender was multivalent, with 'real men' being judged according to different discourses, and also that it functioned along a gradient of relative masculinities. Here it is also connected with the larger group identity, and the results of her investigation into Revelation demonstrate that the 144000 are described in traditionally conflicting terms, having 'mixed gender', so to speak. Stenström's study continues the insight that identity in the New Testament was shaped by new interpretations of gender and masculinity in particular. By traditional standards men were becoming like women and women were becoming like men. Honour in the process was reconfigured. One must wonder how our ancient brothers defended their honour or reacted when hearing that they were not in control of their bodies, that eunuchs and children were ideal models for kingdom membership, that husbands had to be sexually submissive to their wives and that male followers of Jesus were like passive 'virgins' or even the 'bride' of Christ!

\section{POSTCOLONIAL THEORY}

Hans Leander (PhD candidate, Göteborg University, Sweden): Parousia as medicine: A postcolonial perspective on Mark and Christian identity construction (Holmberg \& Winninge 2008:223-246)

Is the Markan Jesus a pro- or anticolonial character? Leander turns the spotlight on early Christianity and its relationship to the Roman Empire and especially how the parousia of Jesus functions in Mark within this context.

Leander at first gives a postcolonial perspective on biblical interpretation. 'Postcolonial' means the creation of power relations during colonisation as well as its lingering after-effects, the consequences of colonialism and the reactions against colonisation. At the same time postcolonialism 'is a highly contested interdisciplinary field of research' (ibid. 2008:226) so Leander goes on to give a selective overview. What he notes is that biblical studies has been criticised for its historical-critical paradigm, whereby the meaning of texts in their historical setting is given exclusive priority, as well as for its claims of neutrality and objectivity. He argues that 'a postcolonial perspective still implies studying the text in different settings, not only the ancient one, and to analyze how it has been part of, as well as resisted, colonial discourses', including those discourses of dominance that exist today (ibid. 2008:228). ${ }^{4}$

Some attention is then given to the work of Gayatra Spivak and Homi Bhabha and their insistence on the unstable meanings of texts (ibid. 2008:229-232). Spivak works with a concept that she labels catachresis, whereby within a colonial discourse, particularly within postcolonial margins, ideas or rhetorical

4. The substance of Leander's investigation, however, is itself historical-critical. At the end of his article he does note that Christian identity, as constructed by Mark, 'could potentially undermine the colonizing hegemony' (Holmberg \& Winninge 2008:245). potentially undermine the colonizing hegemony' (Holmberg \& Winninge 2008:245).
The location of the parousia is on the margins of an empire and was formulated by a differing minority community. 
practices are taken out of their original context and used in such a way that they open up new areas of meaning. Bhabha works with concepts such as hybridity, colonial ambivalence and mimicry. Here the interaction between the coloniser and the colonised brings about changes in consciousness and identity, and mimicry, albeit in imperfect fashion, translates into a form of ironic resistance. These colonial processes occur in a 'third space', on the border between the coloniser and the colonised, where there are the simultaneous forces of repulsion and attraction. This leads to dislocations of given identity positions and results in a space where new identities are negotiated.

Leander then turns his attention to Mark and colonialism and argues that the Markan story must not be seen as purely proor anti-Roman but that a postcolonial perspective invites us to look for traces of ambiguity and hybridity. This is already demonstrated by the beginning of Mark, but the study focuses on Mark 8:31-38 and the parousia of Jesus in power and glory. What we find are the Roman colonial discourse as well as that of local Jewish traditions, used in such a way that they created displacements and destabilisations in the Roman hegemony, resulting in a new (third) social space and renegotiation of identity. Leander dismisses the image of the parousia as simply one colonial discourse of power replacing another; it is more ambivalent and it also evinces mimicry. The first part of Mark, as illustrated by the exorcism of the demoniac, is anti-colonial (Mk 5:1-20), but in Mk 8:31, 34, through the introduction of a suffering-and-death theme, we find a turning point. To 'take up one's cross' can be understood as a catachresis (as Spivak uses it), whereby it becomes a symbol for the life of the community of Jesus believers, which often implied the severance with one's kinship group. The cross opens up a new identity position and new areas of meaning.

Mk 8:38 (Leander incorrectly refers to 8:39) introduces the theme of the parousia, 'where Jesus is undeniably depicted as an authority figure with boundless colonial power' (Holmberg \& Winninge 2008:241). But the threat contained in this saying is not aimed at the colonisers but at the (anti-colonial) disciples, the same ones reluctant to take up their cross.

Rather than being an essential part of an anti-colonial identity construction, the Markan Son of Man helps forming a new kind of identity, characterized by the catachrestical usage of the cross, which goes beyond the dichotomic positions pro- and anticolonial.

(ibid. 2008:241)

And taking the shame of the cross into consideration,

... rather than simply duplicating the shame and mirroring it back as a retribution against the colonizers ... the Markan Jesus uses the Son of Man as a rhetorical medicine for the disciples. The disciples' fear of shame by identification with someone who died on the colonizers' cross is neutralized by the fear of being shamed by the crucified and risen Son of Man. So the Markan parousia can be understood as a medicine against the colonial terror of shaming, a medicine that makes possible the formation of a new identity.

(ibid. 2008:244)

This is an interesting study that explains the subtle and varied dynamics of identity formation on the boundaries between the coloniser and the colonised and how it was given specific treatment by Mark. Oakes's (2005:85) observation that 'Mark's attitude to Rome is more a puzzle than a clear tension' finds an affirming echo. Rome and her demise is not a primary issue for Mark; perhaps it is simply taken for granted, but other issues are more pressing, such as loyalty to Jesus and identifying with the coloniser's cross. What a strange identity!

\section{Christina Petterson (PhD candidate, Macquarie University, Sydney, Australia): Mission of Christ and local communities in Acts (Holmberg \& Winninge 2008:247-268)}

Petterson, in another postcolonial reading, investigates the book of Acts. What is of particular interest to her is the

representation of the local, indigenous communities encountered during the missionary journeys in Acts. How are they portrayed, how do they respond to the missionaries and how are we, as readers, encouraged to understand their response?

(Holmberg \& Winninge 2008:247)

Petterson's aim is also to relate her analysis to information provided by Danish missionaries to the Inuit in Greenland in the late 18th century. She also wants to read 'against' the master narrative of Luke in an attempt to understand what the situation must have looked like from a local perspective.

Petterson looks at some of the pitfalls of postcolonial biblical studies, such as the failure to expose continuities and discontinuities of power within empires and newer forms of imperialism. Postcolonialism is also a term increasingly understood and used as a literary theory, which downplays material reality. This has also affected postcolonial biblical studies since, according to Petterson, textual analysis predominates because of our limited knowledge of the material reality of the biblical texts. Another problem is their function as Scripture, and when seen in conjunction with colonialism, biblical studies shares in the involvement of Western literature in Eurocentrism and subjugation. This can be avoided by arguing that this was not the 'original' intention of the text, but nevertheless, biblical studies is seen as a 'colonizing body of knowledge' in which focus on the ancient world ignores how biblical texts function in contemporary power structures and politics (ibid. 2008:250).

The contribution of R.S. Sugirtharajah to postcolonial biblical criticism is mentioned next. Amongst many contributions to this field of research, he set out to unveil the missionary journey structure in Acts and how it was constructed during the colonial period. He finds Jerusalem as the missionary headquarters as an imposition on the text, which constructed a false situation in which the West is seen as the centre of salvation and the rest of the world is reduced to submissive recipients of the gospel. Petterson appreciates Sugirtharajah's emphasis on the historical conditions in terms of an interest in missionary headquarters and patterns, although she disagrees that this interest is a distortion of the text (ibid. 2008:251-252).

Petterson then turns her attention to three texts in Acts (ibid. 2008:252-264) in which the gospel is brought to Samaria (Acts 8:5-25) and the first Gentiles in Lystra and Derbe in Lycaonia (Ac 14:8-20) and in which the confrontation with silversmiths in Ephesus takes place (Ac 19). Variously, the Samaritans are represented as superstitious or deceived by one of their own, similarly to the descriptions of the Inuit as stupid and gullible. The Lycaonians are portrayed as part of the periphery, everything that the centre is not, similar to how the Orient/ Africa is depicted in the West. The silversmiths in Ephesus are represented as money-hungry souvenir mongers, whipping up an ignorant crowd into a frenzy. The overall ideology of the Lucan narrative is therefore intrinsically useful to undergird the formation of cultural stereotypes and an inflated Western feeling of superiority. This is where the problem lies, since this kind of denigration is perpetuated within the discipline of theology (Holmberg \& Winninge 2008:265).

What are we to do? Petterson suggests that postcolonial biblical criticism, when set within a broader theological agenda, can help. Firstly, there needs to be a recognition of the negative use of biblical texts in colonialism and, secondly, there should be a focus on the liberating potential of these texts. The text can mean many things, 'but if we want to be open-minded towards indifference and sensitive towards oppression, then what should it mean?' (ibid. 2008:267; emphasis original). A theology that pays attention to these sensibilities must be developed.

In the end Petterson's study is not so much about identity in the New Testament but is more concerned with its lingering 
postcolonial effects. Denigrated identities in the New Testament have their counterpart in modern forms of imperialism and, as Petterson points out, contemporary theology cannot be exempted. Past and present realities of colonialism need to intersect but with a focus on identity construction and the production of responsible theology today. The challenge, of course, is whether doing theology, even the most sensitive sort, is not inherently imperialistic as far as claims of correct 'knowledge' or belief systems are concerned. Does theology not always question or to some degree void existing identities of meaning and content? Does sensitive postcolonial biblical criticism require the death of universal proclamation? Is posing the question 'What should it (the biblical texts) mean?' really doing theology (i.e. exegesis is replaced by eisegesis)? These questions are not a form of criticism because we are painfully aware that indifference, denigration, stereotyping and oppression are social realities still experienced today. Petterson's article poses a challenge; hopefully she and others can meet this challenge.

\section{Anna Rebecca Solevåg (PhD candidate, Oslo University, Norway): Perpetua and Felicitas - Reinterpreting empire, family and gender (Holmberg \& Winninge 2008:269-284)}

Strictly speaking, this article does not cover the New Testament and employs more than postcolonial readings by utilising gender studies as well. In her study, Solevåg investigates the figures of Perpetua and Felicitas, the centres of attention in The Martyrdom of Perpetua and Felicitas. They are two of the six martyrs in the narrative, which tells the story of the conflict between Christians and the Roman authorities. Solevåg argues that the conflict occurs in three areas: 'There is the conflict over the understanding of empire, including reverence for the emperor, respect for the Law and acknowledgement of authority and power. There is conflict over family - especially over the role of the paterfamilias and the meaning of motherhood. Finally there is a conflict over the meaning of gender, both concerning the female body and concerning received male and female virtues' (Holmberg \& Winninge 2008:269). It is therefore a conflict with existing power structures, of which she gives an outline as well, and in which context the 'transformation' of Perpetua must be understood (ibid. 2008:272-274).

Solevåg also sees martyrdom texts as conscious efforts to subvert meaning and to create a Christian understanding of society and the self, touching upon the themes mentioned above. God's kingdom supersedes the Roman Empire. The Christian family, in which God is father, replaces the Roman family. Furthermore, the female body is capable of transformation into maleness, taking on male virtues and characteristics such as courage, authority and the ability to initiate action.

Solevåg sees the text as operating on two levels: the historic and the cosmic. Experiences in the ordinary world, especially that of persecution, are given meaning and are interpreted in a visionary world. It is particularly the experience of Perpetua that receives attention, as she experiences a transformation in her relationship to the dominant power structures (Pater Patriae/ empire; paterfamilias/family; and perceptions of masculinity), which are given new meaning. Nevertheless, although the conventional understanding of these areas is rejected, they are still seen as something positive. The meaning of the categories, not the categories themselves, is subverted (ibid. 2008:283).

What we encounter in this study are transformations of identity already identifiable in the New Testament. Solevåg opens these up, however, in the interconnected power structures of the Empire in terms of the transformation experienced by Perpetua that, consequently, leads to her martyrdom. As a reader one can perceive that identity negotiation for the early Christians was inevitably subversive, counter-cultural, even deadly. Christian identity stands out as a process of transformation in an unwilling society bent on anti-transformation, that is, traditionalism, absolute authority and male privilege. It will be interesting to see whether Solevåg applies her attractive study to the period of the New Testament itself or even to contemporary power structures that are often too recognisable in ancient texts.

\section{CONCLUDING OBSERVATIONS}

This collection of articles has both strengths and weaknesses; this is necessarily said with some reservation, hoping that the review performed here is an accurate representation of the arguments. As a reference for methods to study identity formation, however, this collection is most helpful, especially for students being introduced to the various fields of inquiry. The bibliography will also provide guidelines for further reading. For those who specialise in one of the methods on offer the articles invite interaction and further exploration. Some of the methods and conclusions call for further work and clarification. The strength of the book is the scope of inquiry it offers in one volume, and for those who are interested in identity studies it is a welcome resource. It demonstrates that identity is experienced and transformed in various domains and that it is a complex phenomenon interrelated on several social levels. Just bear in mind that this volume does not exhaust all avenues of identity formation. Perhaps the book needed to be called Identity Formation in Judaism and Early Christianity, to cover its scope that is broader than implied in the current title, but this is a minor criticism. The book also contains a few typographical errors that could have been avoided. This being said, the volume is a step forward in research that invites others to advance it even further.

\section{REFERENCES}

Brown, R., 1995, Prejudice: Its social psychology, Wiley-Blackwell, Oxford.

Brown, R., 2001, Group processes: Dynamics within and between groups, 2nd edn., Wiley-Blackwell, Oxford.

Cromhout, M., 2007, Jesus and identity: Reconstructing Judean ethnicity in $Q$ (Matrix: The Bible in Mediterranean context), Cascade Books, Eugene.

Crossan, J.D. \& Reed, J.L., 2004, In search of Paul: How Jesus' apostle opposed Rome's empire with God's kingdom, HarperCollins, New York.

Dunn, J.D.G., 1998, The theology of Paul the apostle, Eerdmans, Grand Rapids.

Dunn, J.D.G., 2007, The new perspective on Paul, Mohr Siebeck, Tübingen.

Esler, P.F., 2003, Conflict and identity in Romans: The social setting of Paul's letter, Fortress Press, Minneapolis.

Hays, R.B., 1989, Echoes of Scripture in the letters of Paul, Yale University Press, New Haven/London.

Holmberg, B. \& Winninge, M., 2008, Identity formation in the New Testament, Wissenschaftliche Untersuchungen zum Neuen Testament 227, Mohr Siebeck, Tübingen.

Horsley, R.A. \& Draper, J.A., 1999, Whoever hears you hears me: Prophets, performance, and tradition in $Q$, Trinity Press International, Harrisburg.

Kloppenborg, J.S., 2000, Excavating Q: The history and setting of the sayings gospel, Fortress Press, Minneapolis.

Luz, U., 2005, Matthew 21-28: A commentary, transl. W.C. Linss Hermeneia, Fortress Press, Minneapolis.

Mournet, T.C., 2005, Oral tradition and literary dependency: Variability and stability in the synoptic tradition and $Q$, Mohr Siebeck, Tübingen.

Moxnes, H., 1996, 'Honor and shame', in R. Rohrbaugh (ed.), The social sciences and New Testament interpretation, pp. 19-40, Hendrickson Publishers, Peabody.

Oakes, P., 2005, 'A state of tension: Rome in the New Testament', in J. Riches and D.C. Sim (eds.), The Gospel of Matthew in its Roman imperial context (Journal for the Study of the New Testament Supplement Series), pp. 75-90, T\&T Clark International, London.

Rohrbaugh, R.L., 2008, 'The social location of the Markan audience', in J.H. Neyrey and E.C. Stewart (eds.), The social 
world of the New Testament: Insights and models, Hendrickson Publishers, Peabody.

Saldarini, A.J., 1992, 'Deligitimation of leaders in Matthew 23', $C B Q 54,659-680$.

Saldarini, A.J., 1994, Matthew's Christian-Jewish community, The University of Chicago Press, Chicago.

Sanders, E.P., 1977, Paul and Palestinian Judaism: A comparison of patterns of religion, SCM and Fortress Press, Minneapolis.

Schüssler Fiorenza, E., 1983, In memory of her: A feminist theological reconstruction of Christian origins, Crossroad, New York.

Sim D.C., 1998, The gospel of Matthew and Christian Judaism: The history and social setting of the Matthean community, T\&T Clark, Edinburgh.
Tajfel, H., 1978, Differentiation between social groups: Studies in the social psychology of intergroup relations, Academic Press, London.

Tajfel, H., 1981, Human groups and social categories: Studies in social psychology, Cambridge University Press, Cambridge.

Tajfel, H. \& Turner, J., 1979, 'An integrative theory of intergroup conflict', in W.G. Austin and S. Worchel (eds.), The social psychology of intergroup relations, pp. 33-47, Brooks/Cole Publishing, Monterey.

Tuckett, C.M., 1996, Q and the history of early Christianity: Studies on $Q$, T\&T Clark, Edinburgh.

Turner, J.C., 1987, Rediscovering the social group: A self-categorization theory, Blackwell, Oxford. 